\title{
NF2/Merlin Inactivation and Potential Therapeutic Targets in Mesothelioma
}

\author{
Tatsuhiro Sato ${ }^{1}$ and Yoshitaka Sekido ${ }^{1,2, *}$ \\ 1 Division of Molecular Oncology, Aichi Cancer Center Research Institute, 1-1 Kanokoden, Chikusa-ku, \\ Nagoya 464-8681, Japan; satot@aichi-cc.jp \\ 2 Department of Cancer Genetics, Nagoya University Graduate School of Medicine, 65, Tsurumai-cho, \\ Showa-ku, Nagoya 464-8603, Japan \\ * Correspondence: ysekido@aichi-cc.jp; Tel.: +81-52-762-6111
}

Received: 28 February 2018; Accepted: 19 March 2018; Published: 26 March 2018

\begin{abstract}
The neurofibromatosis type 2 (NF2) gene encodes merlin, a tumor suppressor protein frequently inactivated in schwannoma, meningioma, and malignant mesothelioma (MM). The sequence of merlin is similar to that of ezrin/radixin/moesin (ERM) proteins which crosslink actin with the plasma membrane, suggesting that merlin plays a role in transducing extracellular signals to the actin cytoskeleton. Merlin adopts a distinct closed conformation defined by specific intramolecular interactions and regulates diverse cellular events such as transcription, translation, ubiquitination, and miRNA biosynthesis, many of which are mediated through Hippo and mTOR signaling, which are known to be closely involved in cancer development. MM is a very aggressive tumor associated with asbestos exposure, and genetic alterations in NF2 that abrogate merlin's functional activity are found in about $40 \%$ of MMs, indicating the importance of NF2 inactivation in MM development and progression. In this review, we summarize the current knowledge of molecular events triggered by NF2/merlin inactivation, which lead to the development of mesothelioma and other cancers, and discuss potential therapeutic targets in merlin-deficient mesotheliomas.
\end{abstract}

Keywords: malignant mesothelioma; neurofibromatosis type 2 (NF2); merlin; Hippo signaling pathway; PI3K/AKT/mTOR signaling pathway

\section{Introduction}

Mutations in the neurofibromatosis type 2 (NF2) gene are responsible for neurofibromatosis 2, a dominantly inherited familial cancer syndrome characterized by the formation of bilateral vestibular schwannomas and meningiomas [1,2]. Besides sporadic schwannomas [3] and meningiomas [4], frequent biallelic inactivation of NF2 was also found in malignant mesothelioma (MM), a very aggressive tumor which is not associated with the NF2 cancer syndrome [5,6]. Tumors carrying NF2 mutations are also observed, albeit infrequently, in multiple organs such as the breast, the prostate, the liver, and the kidney $[7,8]$, indicating a significant role of NF2 in the development of various human malignancies.

Findings in mouse models support the biological function of NF2 as a tumor suppressor gene. Since it was shown that a homozygous mutation in the NF2 gene of mice causes embryonic death by day 6.5 of their development [9], the role of NF2 as a tumor suppressor gene has been studied in mice that are heterozygous for NF2 mutations. It was found to develop a variety of malignant tumors, including lymphoma, sarcoma, and carcinoma $[10,11]$. Furthermore, some studies revealed the involvement of NF2 in the development of malignant plural mesothelioma after asbestos exposure. Thus, heterozygous $\mathrm{NF}^{+/-}$mice had a higher sensitivity to asbestos, which resulted in an increased risk of malignant mesothelioma formation compared to wild-type $\mathrm{NF}^{+/+}$mice $[2,12]$. A direct injection of the Adeno-Cre 
virus into the pleural cavity of adult mice resulted in a conditional knockout of oncosuppressor genes, which further demonstrated that the loss of NF2, together with Tp53 or Ink4a/Arf, frequently causes the development of mesothelioma which closely mimicked human MM [13]. It was also shown that the restoration of NF2 expression in NF2-deficient mesothelioma cells significantly inhibited their growth [14-16]. These in vitro and in vivo data strongly support the role of NF2 inactivation in mesothelioma development.

\section{Domain Organization and Functions of Merlin}

\subsection{NF2 Transcript Variants}

The NF2 gene is located in the chromosomal region 22q12 [1,17]; the gene contains 17 exons and spans approximately $95 \mathrm{~kb}$ of DNA. NF2 transcripts undergo alternative splicing, thereby generating multiple isoforms [18], and variable NF2 transcripts are observed in human mesotheliomas [5,12]. Two transcripts, one lacking exon 16 and the other containing all 17 exons, are the predominant variants encoding isoforms I and II; the first contains 595 amino acids, while the second, which is generated by the insertion of exon 16 into mRNA which creates a new stop codon, contains 590 amino acids and is identical to isoform I in the first 579 residues (Figure 1A). Initially, it was thought that isoform II lacked anticancer activity $[19,20]$; however, later studies showed that both isoforms exhibited the function of tumor suppression [21-23].

(a)

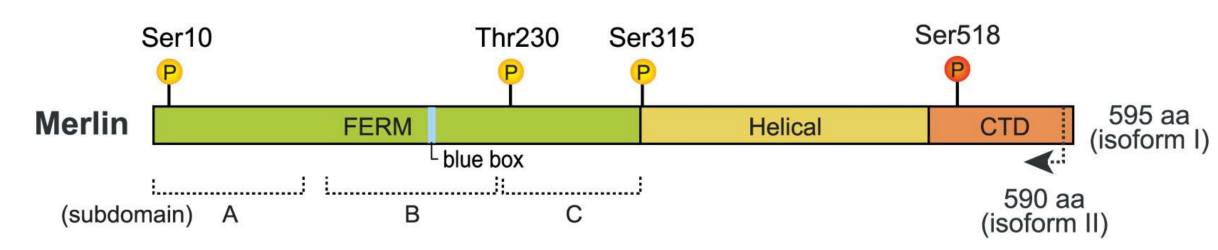

(b)

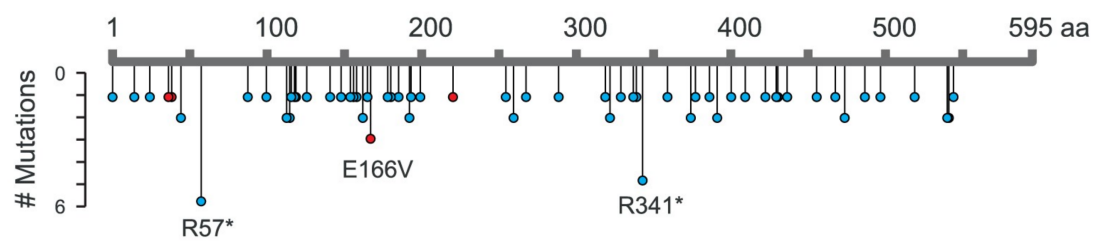

(c)

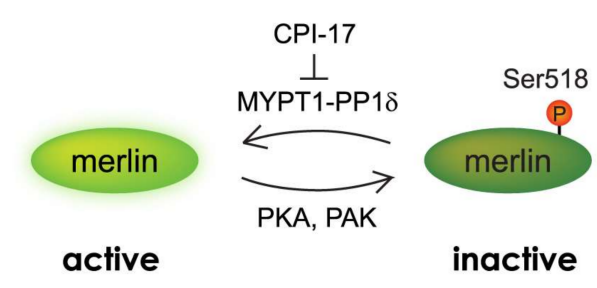

(d)

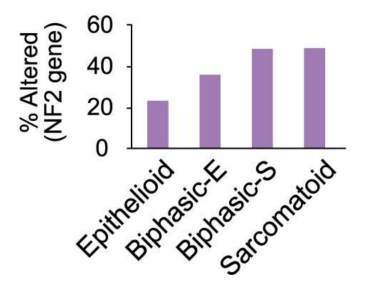

Figure 1. Mechanisms underlying the activation/inactivation of merlin. (a) Domain organization of merlin. The protein consists of the N-terminal FERM (band 4.1/ezrin/radixin/moesin) domain (green) comprising three subdomains (A, B, and C), a central helical domain (yellow), and a C-terminal domain (CTD, orange). Major phosphorylation sites are indicated; (b) NF2 mutations and their frequency in pleural and peritoneal cancers. Nonsense/frameshift (blue) and missense (red) mutations registered in COSMIC (Catalogue of Somatic Mutations in Cancer; http:/ / cancer.sanger.ac.uk/cosmic/) as of 27 February 2018, are mapped; (c) Phosphorylation-dependent inactivation of merlin. Phosphorylation at Ser518 inactivates merlin and inhibits its growth suppression activity; (d) Frequency of genetic alterations in the NF2 gene, including mutations, fusions, and copy number variations in different subtypes of malignant pleural mesothelioma based on an analysis of 211 malignant plural mesothelioma samples. The data were adapted from Bueno et al. [24]. 


\subsection{Domain Organization}

The NF2 gene product, named merlin, is widely expressed in various human tissues and is most closely related to the ezrin/radixin/moesin (ERM) family proteins, which are localized at cell-surface structures such as ruffling membranes and cell-cell adhesion sites, and connect actin filaments to the plasma membrane. The significant similarity in amino acid sequences between merlin and ERM proteins suggests that merlin can be associated with the actin cytoskeleton and the organization of membrane domains [25].

A structural analysis shows that merlin consists of three domains: the N-terminal FERM (band 4.1, ezrin, radixin, moesin) domain containing three subdomains (A, B, and C), the central helical domain, and the C-terminal domain (CTD) (Figure 1A). Merlin shares 45-47\% sequence similarity with the ERM family members, especially in the conserved FERM domain (60-70\%). The FERM of merlin binds to membrane proteins such as hyaluronate receptor CD44 [26,27], adaptor molecule $\mathrm{Na}^{+} / \mathrm{H}^{+}$exchanger three, regulating factor one (NHERF/EBP50) [28,29], and E-cadherin [30]. Furthermore, the FERM mediates protein binding to phospholipids such as phosphatidylinositol 4,5-bisphosphate (PIP2) [31,32]. Despite the similarity in the binding properties between merlin and ERM proteins, their CTDs show distinct binding preferences. The CTDs of ERM proteins have actin-binding sites [33] linking the plasma membrane to the actin cytoskeleton, whereas merlin lacks the region corresponding to the C-terminal F-actin-binding site [34] and interacts with actin fibers through residues 1-27 and 280-323, which seem to be sufficient for the binding [35]. Moreover, merlin has a unique seven-amino-acid stretch (residues 177-183) in the FERM domain, named the 'blue box', which is conserved from fly to mammalian proteins but is lacking in ERM family members [34,36]. Alanine substitution in, or deletion of, this region produces unique merlin mutants, which have dominant-negative activity and result in an excessive proliferation of wing epithelial cells in flies [36] and a loss of contact inhibition in mammalian cells [26,37]. The unique characteristics of merlin domains suggest that the regulation of merlin is distinct from that of ERM proteins.

\subsection{Molecular Conformation and Phosphorylation}

ERM proteins have a 'closed' inactive conformation formed by the binding of CTD to the $\mathrm{N}$-terminal FERM, whereas the phosphorylation of C-terminal residues disrupts the interaction, resulting in the 'open' active state, where the released FERM and CTD can bind to cell adhesion molecules and actin filaments, respectively [31]. Although a C-terminal phosphorylation site, threonine 576, critical for the conformational change in ERM proteins, is also conserved in merlin; the Thr576Ala substitution does not affect merlin's ability to suppress cell growth and motility [38]. Aside from this, the phosphorylation of merlin at serine 518 abrogates its growth inhibition activity [38,39]. These findings indicate that in merlin, phosphorylation causes inactivation, which is in contrast to its effect in ERM proteins (Figure 1C).

Merlin phosphorylation at Ser518 was frequently observed in mesothelioma cells expressing full-length merlin [12]. Moreover, CPI-17, a cellular inhibitor of myosin phosphatase targeting subunit 1 (MYPT1-PP18), was increased in mesothelioma cells with full-length NF2 compared to normal pleura or mesothelioma with truncated NF2 [38]. As MYPT1-PP1 $\delta$ dephosphorylates merlin at Ser518 [40], CPI-17 upregulation would result in an increased phosphorylation and inactivation of merlin (Figure 1C). These findings suggest that merlin can be inactivated not only by mutations but also through posttranslational modifications occurring in mesothelioma cells.

The Ser518 phosphorylation in merlin is independently catalyzed by distinct protein kinases such as p21-activated kinase (PAK) [41-43] and protein kinase A (PKA) [44]. PAK causes a phosphorylationdependent inactivation of merlin and promotes the loss of contact inhibition of proliferation [45], whereas PKA, in addition to Ser518, also phosphorylates Ser10 that is not conserved in ERM proteins, which results in increased cell migration [46]. Another protein kinase, AKT, phosphorylates merlin at Thr230 and Ser315, which appears to stimulate ubiquitin-dependent protein degradation [47]. 
Given the data on ERM proteins, Ser518 phosphorylation in merlin has been suggested to change its conformation from a 'closed' to an 'open' state [48]. Although the FERM and the CTD of merlin bind each other, their mutual affinity is low compared to that in ERM proteins [49], suggesting that merlin may not form a fully closed form. Instead, phosphorylation was shown to rather strengthen the head-to-tail folding in merlin [23]. Analysis by fluorescence resonance energy transfer (FRET) suggests that phosphorylation causes a subtle conformation change in merlin [50]. Furthermore, although merlin isoform II does not form the 'closed' state since it lacks five C-terminal residues [51], both isoforms I and II exhibit antitumor activity [21-23]. Cumulatively, these findings suggest that the phosphorylation at Ser518 would inactivate merlin without the accompanying dynamic conformational change observed in ERM proteins.

\subsection{NF2 Inactivation in Mesothelioma}

In addition to a frequent loss of the 22q12 region, which is the locus of the NF2 gene, mutations within the entire NF2 coding region are common for mesothelioma (Figure 1B). Nonsense mutations either totally abolish merlin expression or lead to the production of truncated forms. The functional activity of the truncated merlin variants, especially those with a short deletion at the C-terminus, has not been fully characterized. However, it was shown that the mutant with a C-terminal deletion of 40 residues was incapable of restoring proper growth inhibition in NF2-null mesothelioma cells [15], and that merlin truncated by 63 residues at the C-terminus did not cause growth arrest of primary Schwann cells [13], indicating the importance of the CTD for the antitumor activity of merlin. Therefore, nonsense mutations in NF2, even those occurring close to the C-terminus, are suggested to produce functional defects and are responsible for mesothelioma development. In contrast, the impact of missense mutations that cause amino acid substitutions is less understood, and it is unclear as to how and to what extent individual mutations affect merlin tumor-suppressive function. Although the pathogenic activity of several missense mutants identified in tumors have been studied [14], further investigation is required for a complete understanding of the effect produced by merlin mutations on tumor progression. In addition, NF2 gene rearrangements are also frequently detected in MM, and each NF2 gene fusion variant was thought to cause functional inactivation [24].

Regarding gene mutation frequency in MM, gene alterations in NF2 are considered to be the second most common after those in BAP1. Developed mesothelioma tumors have different histological subtypes: epithelioid, sarcomatoid, and biphasic MMs. An expression analysis of 211 malignant plural mesothelioma samples suggested that among the subtypes, sarcomatoid tumors had the highest NF2 mutation rate, while epithelioid tumors had the lowest NF2 mutation rate [24] (Figure 1D). Furthermore, hemizygous NF2 loss has been shown to decrease both the overall survival and the progression-free survival in a cohort of 86 peritoneal mesothelioma patients [52]. These data suggest that NF2 inactivation might be involved in the epithelial-mesenchymal transition during metastasis, and that the development of sarcomatoid mesotheliomas is characterized by a poorer overall survival compared to the epithelioid subtype.

\subsection{Loss of Contact Inhibition in NF2-Deficient Cells}

Contact inhibition, a regulatory mechanism providing cell growth arrest at confluence in tissue culture, is frequently disrupted in cancer cells [53], and NF2-null cells grow to a significantly higher density compared to wild-type cells, suggesting that NF2 controls tumor progression. The mechanism underlying the merlin regulation of growth arrest in response to cell confluence has been addressed in several studies. For example, it has been shown that merlin forms a complex with CD44, which is activated by the stimulation of extracellular hyaluronate, resulting in growth inhibition of rat schwannoma cells in vitro. Other studies have suggested that merlin regulates contact inhibition through small GTPase Rac1 [45,54], $\alpha$-catenin, cell-polarity protein Par3 [55], and a tight-junction-associated complex composed of angiomotin (AMOT), Patj, and Pals1 [48] (Figure 2, 
shown in pink). These findings suggest that merlin could sense its environmental conditions and control cell growth via complex interactions with signaling proteins involved in cell-cell adhesion.

\subsection{Subcellular Localization}

FERM domain-containing proteins link plasma membrane receptors to cytoskeleton components [12]. Consistent with this notion, immunostaining with merlin-specific antibodies detects merlin at the cell membrane or the ruffling edges in human fibroblasts, meningioma cells, and Schwann cells [56,57]. Although the localization of the wild-type or the mutant merlin in mesothelial and mesothelioma cells is not defined, we have observed exogenously expressed full-length V5-tagged merlin both at the plasma membrane and in the cytoplasm of merlin-negative mesothelioma cells [58]. However, as merlin localization is dynamically regulated in response to various signals (described below), a further detailed investigation is necessary.

\section{Proteins and Signaling Related to Merlin's Functions}

\subsection{Hippo Signaling Pathway}

Merlin exerts its tumor-suppressive effects by controlling the expression of oncogenic genes through the activation of Hippo signaling (Figure 2, shown in orange). The Hippo pathway is composed of core proteins including MST1/2 (Mammalian STE20-Like Protein Kinases), SAV1 (Salvador Family WW Domain Containing Protein 1), MOB (MOB Kinase Activators), and LATS1/2 (Large Tumor Suppressor Kinase 1/2) [59]. At the plasma membrane, merlin recruits LATS1/2 kinases which directly phosphorylate the downstream effectors of the Hippo pathway, YAP (Yes-Associated Protein) and its paralogue TAZ (WW Domain-Containing Transcription Regulator 1, alternatively WWTR1), thus preventing their translocation to the nucleus and inhibiting their function as transcription co-activators. Alternatively, Hippo pathway inactivation induces an accumulation of underphosphorylated YAP and TAZ in the nucleus and their association with DNA-binding TEAD (TEA Domain Transcription Factor) family proteins, which upregulates the transcription of multiple oncogenic genes [60]. Along with NF2 mutations, gene alterations are also frequently observed in Hippo pathway components, including LATS1/2, SAV1, and LIM-domain containing protein AJUBA, a Drosophila djub homolog and LATS1/2 binding partner [61,62]. High-level amplification of the 11q22 locus encompassing the YAP gene was also observed in a small subset of MMs [58]. These results indicate that the disruption of Hippo signaling plays a central role in the transformation of mesothelial cells.

YAP activation in mesothelial cells drastically changes their behavior. Kakiuchi et al. [63] have shown that the expression of constitutively active YAP Ser127Ala mutants in immortalized mesothelial cells promotes their growth in vitro, as well as tumor formation after their transplantation in mice. Conversely, YAP knockdown inhibits cell growth, motility, and invasion in mesothelioma cells with activated YAP, but did not show any effects in cells without YAP activation [64]. Furthermore, these studies showed that the YAP-dependent transcriptional activations of cyclin D2 (CCND2), forkhead box M1 (FOXM1), and phospholipase C beta 4 (PLCB4) are involved in mesothelioma cell growth $[63,64]$, suggesting that activated YAP influences diverse cellular processes, thereby resulting in mesothelial cell transformation. The role of TAZ in mesothelioma has not been defined yet, but considering its functional redundancy with YAP, the oncogenic function of TAZ could be predicted.

\subsection{DCAF1}

It has been reported that merlin can translocate into the nucleus, where it binds to DCAF1 (also known as VprBP) through the N-terminal FERM domain [65]. DCAF1 is a substrate adaptor of E3 ubiquitin ligase CRL4 ${ }^{\mathrm{DCAF} 1}$ containing CUL4 and DDB1. The interaction between merlin and DCAF1 depends on merlin activation, since neither the Ser518Asp phosphomimetic mutant, nor the Ser64Ala mutant, which lacks tumor-suppressor activity, bind to CRL4 ${ }^{\mathrm{DCAF} 1}$. Merlin inhibits the activity 
of CRL4 ${ }^{\mathrm{DCAF} 1}$, which regulates ubiquitination of target proteins. It was shown that LATS1/2 are functional targets of CRL4 ${ }^{\mathrm{DCAF} 1}$ and that in tumors with mutated NF2, such as mesothelioma, activated CRL4 induces LATS1/2 ubiquitination to promote their degradation and YAP/TAZ activation, thus stimulating oncogenesis [66] (Figure 2, shown in purple). These results suggest that DCAF1 and CRL4 ${ }^{\text {DCAF1 }}$ are potential therapeutic targets for merlin-deficient mesothelioma. Cooper et al. [67] tested whether CRL4 ${ }^{\text {DCAF1 }}$ inhibition with NEDD8-activating enzyme (NAE) inhibitor MLN4924 could suppress the growth of tumor cells carrying NF2 mutations. MLN4924 alone caused only a moderate inhibition of mesothelioma cell growth, but the combination of MLN4924 and GDC-0980, an mechanistic target of rapamycin/phosphatidylinositol 3-kinase (mTOR/PI3K) inhibitor, strongly suppressed cell proliferation. Despite blocking a broad spectrum of Cullin-RING E3 ligases including CRL4 ${ }^{\text {DCAF1 }}$, NF2-NAE inhibitors could be a promising target for therapeutic intervention in patients with merlin-negative mesothelioma.

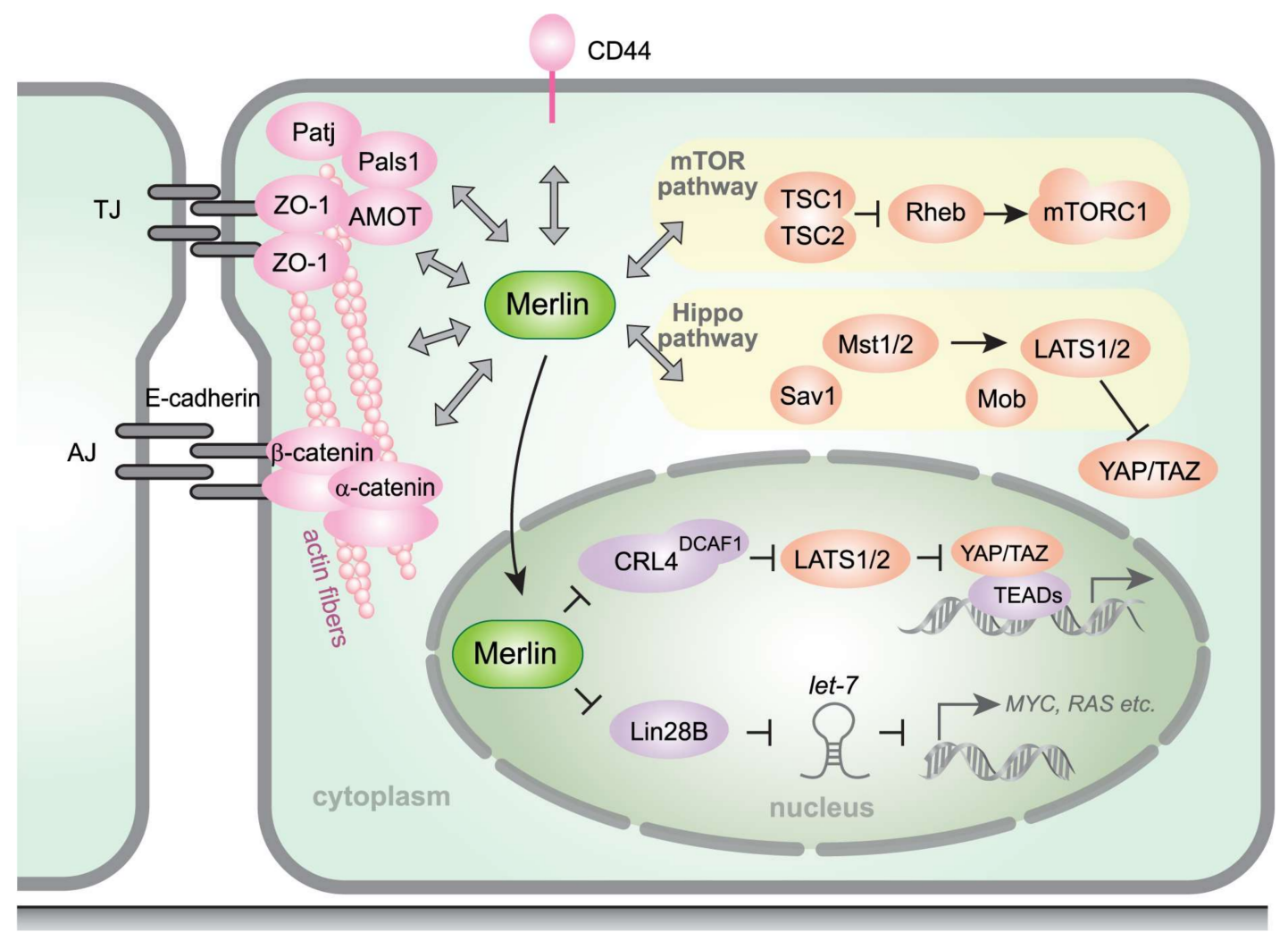

Figure 2. A model of the NF2/merlin signaling pathway. Merlin is involved in contact inhibition by interacting with many membrane-associated proteins such as CD44 [26,27], the angiomotin (AMOT) -Patj-Pals1 complex [48], E-cadherin- $\alpha$-catenin [30,55], and actin fibers. A loss of merlin expression disrupts cancer-related signaling through the Hippo and mTOR pathways. Merlin is also localized in the nucleus where it binds to and inhibits E3 ubiquitin ligase CRL4 ${ }^{\mathrm{DCAF} 1}$, which promotes LATS1/2 degradation [66,67], and RNA-binding protein Lin28B, which suppresses let-7 miRNAs that are involved in the silencing of oncogenes such as MYC and RAS [68]. TJ: tight junction; AJ: adherens junction; ZO-1: Zonula occludens-1; AMOT: angiomotin; mTOR: mechanistic target of rapamycin; TSC1/2: tuberous sclerosis complex 1/2; Rheb: Ras homolog enriched in brain; Sav1: Salvador Family WW Domain Containing Protein 1; Mst1/2: mammalian Ste20-like kinase 1/2; Mob: Mps one binder kinase activator-like protein; YAP: yes-associated protein 1; TAZ: WW domain-containing transcription regulator 1; CRL4: Cullin-RING ubiquitin ligase 4; DCAF1: DDB1- and CUL4-associated factor 1; LATS1/2: large tumor suppressor kinase 1/2; TEAD: TEA domain transcription factor; Lin28B: lin-28 homolog B. 


\subsection{PI3K/AKT/mTOR Signaling Pathway}

mTOR is a serine/threonine kinase that plays a key role in cell growth and proliferation. The mTOR signaling pathway has been reported to be frequently activated in a variety of human malignancies, indicating its close involvement in carcinogenesis.

mTOR is composed of two distinct complexes, mTOR complex 1 (mTORC1) and mTOR complex 2 (mTORC2) [69,70]; both of them contain mTOR kinase and a mTORC subunit mLST8, which is suggested to stabilize the structure of the MTOR catalytic domain [71]. mTORC1 binds to raptor, whereas mTORC2 binds to rictor and Sin1, forming functional kinase complexes. mTORC1 and its activator Rheb have been shown to enhance protein translation and pyrimidine nucleotide biosynthesis, thereby promoting cell growth and proliferation [72-74].

The involvement of the mTOR pathway in mesothelioma formation has been suggested in several studies. Thus, López-Lago et al. [75] showed, using a panel of malignant mesothelioma cell lines, that the loss of merlin correlated with the activation of mTORC1 signaling and the sensitivity to rapamycin. Similarly, James et al. [76] reported that merlin-deficient meningioma cells also exhibited constitutive mTORC1 activation and increased growth. Furthermore, it was demonstrated that the concurrent loss of Tp53 and tuberous sclerosis 1 (TSC1), a negative regulator of Rheb-mTORC1 signaling, induces the development of peritoneal mesothelioma in mice [77]. Immunohistochemical analysis of human mesotheliomas revealed the hyperactivation of $\mathrm{mTORC} 1$ and the reduced expression of TSC2, which binds to TSC1 and negatively regulates the activation of mTORC1 by Rheb. These findings suggest that mTOR activation caused by merlin inactivation plays a significant role in mesothelioma development (Figure 2, shown in orange).

The deregulation of mTORC1 signaling in mesothelioma cells can be attributed to changes in the state of various upstream effectors. AKT, an mTORC1 activator and mTORC2 substrate, is stimulated in more than $60 \%$ of malignant mesothelioma cell lines and tumors [78,79]; furthermore, the homozygous deletion of PTEN, a negative regulator of AKT signaling, has also been reported in mesothelioma cells [78,79]. PTEN loss leads to an increase in phosphatidylinositol $(3,4,5)$-triphosphate (PIP3), resulting in the activation of both mTORC1 and mTORC2 signaling. These data suggest that the activation of mTORC1, as well as mTORC2, may be involved in mesothelioma development. On the other hand, no activating mutations in the MTOR, nor the RHEB genes, have been identified in mesothelioma cells to date, although such mutations were shown to cause the hyper-activation of mTORC1 $[80,81]$ observed in mesothelioma. The biological role of mTORC1 in mesothelioma formation is now beginning to be examined.

\subsection{Lin28B and let-7 miRNAs}

An RNA-binding protein, Lin28B, has been recently reported to be an alternative binding partner of merlin. Lin28B is involved in cell growth and reprogramming [82,83] and suppresses the biogenesis of the let-7 microRNAs (miRNAs) that function as tumor suppressors by silencing the expression of several oncogenes such as MYC and RAS [84,85]. Hikasa et al. [68] found that merlin bound to Lin28B through the FERM domain and translocated Lin28B from the nucleus to cytoplasm, leading to let-7 miRNA maturation (Figure 2, shown in purple). The association between merlin and Lin28B is induced when merlin is dephosphorylated, which occurs at high cell density, suggesting a novel mechanism in which merlin exerts cell-density-dependent tumor suppression through let-7 miRNA maturation.

\subsection{TRAF7}

Recurrent mutations in the TRAF7 gene are observed in mesothelioma cells. TRAF7 belongs to tumor necrosis factor (TNF) receptor-associated factors (TRAFs) possessing E3 ubiquitin ligase activity [86], and it was shown to promote ubiquitination of an apoptosis inhibitor, FLIP [87], which is increased in mesothelioma cells [88]. FLIP inhibition by small interfering RNA (siRNA) sensitizes 
mesothelioma cells to Fas- and TRAIL-induced apoptosis, suggesting a role of FLIP in protecting cells from death signals. Interestingly, TRAF7 and NF2 mutations are mutually exclusive in malignant pleural mesothelioma [24] as well as in meningioma [89], suggesting that merlin and TRAF7 may use a common signal transduction pathway.

\section{Potential Molecular Targets in Merlin-Negative Mesothelioma}

\subsection{FAK Inhibitors}

Focal adhesion kinase (FAK) is a serine/threonine kinase that mediates signals from focal adhesion complexes to the cell growth and migration machinery. FAK is elevated in most human cancers, and its inhibition has been recognized as a novel approach to targeted anticancer therapy against various types of solid tumors. In 2014, Shapiro and colleagues [90] reported that a beneficial effect of an FAK inhibitor, VS-4718 (alternatively PND-1186), on MM cells lacking merlin expression was the increased sensitivity of MM cells to VS-4718 in vitro and in tumor xenograft models. Therefore, FAK inhibitors were considered as potential candidates for mesothelioma therapy. However, a phase II clinical trial investigating the effects of an FAK inhibitor, defactinib (VS-6063), on merlin-deficient mesotheliomas was terminated early due to its futility, and the reason for the poor clinical performance is currently unclear. A recent study on the pharmacological effects of FAK inhibitors has demonstrated a significant correlation between E-cadherin mRNA levels and VS-4718 in merlin-negative mesothelioma [15], suggesting that E-cadherin may serve as a promising biomarker for predicting the response to FAK inhibitors in mesothelioma, which should be tested in clinical settings.

\subsection{YAP Inhibitors}

The screening of more than 3300 Food and Drug Administration (FDA)-approved small molecules resulted in the identification of verteporfin as a novel compound that disrupts the YAP-TEAD interaction and inhibits YAP oncogenic activity [91]. Verteporfin, a benzoporphyrin derivative, is currently used in clinics as a photosensitizer in photodynamic therapy for macular degeneration. The compound is activated by $690 \mathrm{~nm}$ far-red light, generating reactive oxygen species (ROS) which eliminate abnormal blood vessels; however, its inhibition of YAP-TEAD interactions does not require light activation. Several in vitro studies revealed that verteporfin can suppress the growth, the migration, and the tumorsphere formation of cultured MM cells [92,93]. Recently, CIL56 (also named CA3), a small molecule that induces cellular ferroptosis through ROS production [94], has been identified as a novel YAP inhibitor. By preventing the interaction between YAP and TEAD, CIL56 strongly inhibited esophageal adenocarcinoma cell growth both in vitro and in vivo [95]. Therefore, YAP inhibitors may be effective anticancer drugs for mesothelioma and other tumors in which $\mathrm{YAP} / \mathrm{TAZ}$ are activated through the disruption of the Hippo pathway.

In addition to the nucleocytoplasmic shuttling of YAP/TAZ, a recent study revealed a mechanism for the intracellular translocation of TEAD proteins. The findings of Lin et al. [96] suggest that environmental stresses such as osmotic stress, high cell density, and cell detachment promote TEAD translocation from the nucleus to the cytoplasm via p38 mitogen-activated protein kinase (MAPK). Interestingly, TEAD nucleocytoplasmic transfer occurred in a Hippo-independent manner and suppressed YAP and YAP-dependent cancer cell growth, suggesting that the regulation of TEAD translocation might serve as another therapeutic strategy in merlin-deficient tumors.

\section{3. mTOR Inhibitors}

Given the emerging role of mTOR in mesothelioma development and proliferation, mTOR inhibitors are thought to be promising drugs against merlin-negative mesothelioma. Unfortunately, however, a phase II clinical trial of everolimus, a first-generation mTOR inhibitor rapamycin analog (so-called rapalog), demonstrated that there was insufficient activity in patients with advanced 
mesothelioma [97]. The reason for this limited success is not fully understood; it is possible that certain rapamycin-resistant functions of mTORC1 [98] may account for the low efficacy of rapalogs.

To date, various types of improved mTOR inhibitors have been developed. Second-generation mTOR inhibitors (also called ATP-competitive mTOR inhibitors) directly compete with ATP for the binding to the mTOR kinase domain, thus completely inhibiting both mTORC1 and mTORC2. $\mathrm{PI} 3 \mathrm{~K} / \mathrm{mTOR}$ dual inhibitors also target the ATP-binding pocket; the advantage of these compounds is that they recognize the ATP-binding site not only in mTOR but also in PI3K. Considering the reports of mTORC2 activation in mesothelioma cells due to the loss of PTEN, which is an mTORC2 negative regulator, or the increased phosphorylation of mTORC2 substrate AKT [79,99], PI3K/mTOR dual inhibitors are predicted to be more effective in suppressing mesothelioma growth than rapalogs. Moreover, a combination treatment with mTOR or PI3K/mTOR inhibitors together with other antitumor drugs appears to be a reasonable approach, because mTOR signaling is involved in a compensatory pathway that renders cancer cells drug resistant; thus, increased mTORC1 activity in breast and pancreatic cancer cells confers resistance to cyclin-dependent kinase 4/6 (CDK4/6) inhibitors $[100,101]$. Although in vivo experiments are lacking, in vitro data indicate that a combination treatment with the CDK4/ 6 inhibitor, palbociclib, and a PI3K/mTOR dual inhibitor exerts a synergistic effect on mesothelioma cell growth [102].

Recently, a third-generation mTOR inhibitor which overcomes the resistance to first- and second-generation mTOR inhibitors has been developed [103] and already showed promise by exhibiting a higher efficacy in glioblastomas compared to previous mTOR inhibitors [104]. Although the antitumor activity of the new mTOR inhibitors against mesothelioma has yet to be demonstrated, enhanced clinical benefits can be expected.

\subsection{Statins}

Statins are inhibitors of 3-hydroxyl-3-methyl coenzyme A (HMG-CoA) reductase, the rate-limiting enzyme of the mevalonate pathway for the biosynthesis of mevalonate and downstream isoprenoids, which are suggested to have beneficial effects on several cancers, including colorectal cancer, breast cancer, and melanoma [105]. The therapeutic potential of statins for suppressing mesothelioma cell growth has been reported in vitro and in mouse xenografts [106,107]. Furthermore, statins are suggested to have synergistic or additive antitumor effects when used with other drugs [108-110]. Recently, it was reported that mesothelioma cells with NF2 and/or LATS2 mutations were more sensitive to fluvastatin compared to those with BAP1 mutations [111], whereas merlin-negative breast cancer cells showed sensitivity to simvastatin [112]. The regulation of YAP and TAZ through the mevalonate pathway [113] suggests that statins may show a more significant effect on cell growth in NF2-deficient mesothelioma and other types of tumors.

\subsection{COX2 Inhibitors}

It has been demonstrated that YAP activation in NF2-null Schwann cells promotes the transcription of the PTGS2 gene encoding cyclooxygenase 2 (COX-2), the key enzyme in prostaglandin biosynthesis. Interestingly, the treatment of NF2-null Schwann or schwannoma cells with a COX-2 inhibitor, celecoxib, dramatically inhibited cell growth in vitro and in vivo [114], which suggests that COX-2 is a potential therapeutic target in NF2-null tumors. However, a recent study showed that celecoxib failed to prevent the generation of schwannomas in a genetically engineered mouse model of NF2 inactivation, although COX-2 expression was increased in tumors that developed in these mice [115]. Considering the controversial results on COX-2 as a target in NF2-inactive tumors, further investigations are required in this direction.

\section{Conclusions}

Malignant mesothelioma is highly refractory to conventional therapies, and the current chemotherapeutic approach approved in clinics is still based on a combination of platinum and 
an antifolate, pemetrexed [116]. NF2 is one of the most frequently mutated genes in mesothelioma; therefore, the restoration of NF2 functions is expected to cure a large population of mesothelioma patients. However, the introduction of tumor suppressor genes in every tumor cell and the subsequent expression of the encoded proteins at levels that are comparable to those of normal cells remain highly challenging [117]. Growing evidence demonstrates that merlin is distributed in multiple subcellular compartments and suppresses a number of proteins and signaling pathways that are related to tumor progression [118]. Once NF2 is inactivated, these oncogenic mechanisms are constitutively induced, conferring malignant phenotypes to the cells; therefore, targeting merlin-dependent molecular pathways is a promising strategy for the treatment of NF2-deficient cancers. The restoration of the Hippo signaling and the inhibition of the PI3K/AKT/mTOR pathway are predicted to exert potent anticancer effects, but the clinical performance of the perspective drugs has not yet been evaluated, and the mechanisms underlying NF2 control of these signaling pathways in mesothelial and other cells are still unknown.

Although NF2 is frequently inactivated in MMs, recent progress in NF2-targeted therapies has been limited [119]. To search for more effective drugs against NF2-deficient mesothelioma cells, we have to understand when, where, and how merlin exerts its tumor-suppressive effects, especially in mesothelial cells. Further, the roles of downstream signals that are activated by NF2 loss in mesothelioma progression also remain incompletely defined. For example, is the activation of YAP via the inactivation of the Hippo signaling pathway enough for mesothelioma formation? If so, why are YAP gene mutations that constitutively activate their transcription activity undetected in MMs? The activation of $T A Z$ in merlin-deficient MM cells should be evaluated as a potential key oncogene that drives tumor initiation and progression together with YAP. It is to be noted that NF2 loss might be involved in drug resistance. A genome-wide CRISPR screen in human cells has identified NF2 as the highest-ranking candidate whose loss is involved in the resistance to vemurafenib, a therapeutic RAF inhibitor [120]. Future studies focusing on defining the alteration of molecular networks caused by the loss of merlin expression would further foster the development of new therapeutic strategies in mesothelioma.

Acknowledgments: This work was supported in part by JSPS KAKENHI (15K19015, 16H04706, 17K19628), Takeda Science Foundation (for Tatsuhiro Sato), and AMED P-CREATE.

Author Contributions: Tatsuhiro Sato and Yoshitaka Sekido conceived, wrote, and critically proof-read the article.

Conflicts of Interest: Collaboration grant: Kyowa Hakko Kirin Co., Ltd., (Tokyo, Japan) and Eisai Co., Ltd., (Tokyo, Japan). The founding sponsors had no role in the writing of the manuscript. The founding sponsors had no role in the design of the study; in the collection, analyses, or interpretation of data; in the writing of the manuscript, and in the decision to publish the results.

$\begin{array}{ll}\text { Abbreviations } & \\ \text { AMOT } & \text { angiomotin } \\ \text { BAP1 } & \text { BRCA1 Associated Protein 1 } \\ \text { cCNclin D2 } \\ \text { Cyclin-dependent kinase } \\ \text { COX-2 } & \text { cyclooxygenase } 2 \\ \text { CPI-17 } & \text { protein kinase C-potentiated inhibitor protein of 17 kDa } \\ \text { CRL4 } & \text { Cullin-RING ubiquitin ligase } 4 \\ \text { CTD } & \text { C-terminal domain } \\ \text { CUL4 } & \text { Cullin } 4 \\ \text { DCAF1 } & \text { DDB1- and CUL4-associated factor 1 } \\ \text { DDB1 } & \text { damaged DNA binding protein 1 } \\ \text { ERM } & \text { ezrin/radixin/moesin } \\ \text { FAK } & \text { focal adhesion kinase } \\ \text { FDA } & \text { Food and Drug Administration } \\ \text { FERM } & \text { band 4.1/ezrin/radixin/moesin } \\ \text { FLIP } & \text { caspase-like apoptosis regulatory protein }\end{array}$




\begin{tabular}{|c|c|}
\hline FOXM1 & forkhead box M1 \\
\hline LATS1/2 & large tumor suppressor kinase $1 / 2$ \\
\hline Lin28B & $\operatorname{lin}-28$ homolog B \\
\hline MAPK & mitogen-activated protein kinase \\
\hline mLST8 & mammalian lethal with Sec13 protein 8 \\
\hline MM & malignant mesothelioma \\
\hline Mob & Mps one binder kinase activator-like protein \\
\hline mTOR & mechanistic target of rapamycin \\
\hline mTORC & mTOR complex \\
\hline MST1/2 & mammalian Ste20-like protein kinase $1 / 2$ \\
\hline MYPT1-PP1 & myosin phosphatase target subunit 1-protein phosphatase $1 \delta$ \\
\hline NAE & NEDD8-activating enzyme \\
\hline NF2 & neurofibromatosis type 2 \\
\hline PAK & p21-activated kinase \\
\hline Pals1 & protein associated with Lin7-1 \\
\hline Patj & Pals1-associated tight junction protein \\
\hline PI3K & phosphatidylinositol 3-kinase \\
\hline PKA & protein kinase $\mathrm{A}$ \\
\hline PLCB4 & phospholipase $C$ beta 4 \\
\hline PTEN & phosphatase and tensin homolog \\
\hline Rheb & Ras homolog enriched in brain \\
\hline ROS & reactive oxygen species \\
\hline SAV1 & Salvador Family WW Domain Containing Protein 1 \\
\hline siRNA & small interfering RNA \\
\hline TAZ & WW domain-containing transcription regulator 1 \\
\hline TEAD & TEA domain transcription factor \\
\hline TNF & tumor necrosis factor \\
\hline TRAF & TNF receptor-associated factor \\
\hline TRAIL & TNF-related apoptosis inducing ligand \\
\hline TSC1/2 & tuberous sclerosis complex subunit $1 / 2$ \\
\hline VprBP & viral protein $\mathrm{R}$ (VPR)-binding protein \\
\hline YAP & Yes-associated protein 1 \\
\hline $\mathrm{ZO}-1$ & Zonula occludens-1 \\
\hline
\end{tabular}

\section{References}

1. Trofatter, J.A.; MacCollin, M.M.; Rutter, J.L.; Murrell, J.R.; Duyao, M.P.; Parry, D.M.; Eldridge, R.; Kley, N.; Menon, A.G.; Pulaski, K.; et al. A novel moesin-, ezrin-, radixin-like gene is a candidate for the neurofibromatosis 2 tumor suppressor. Cell 1993, 72, 791-800. [CrossRef]

2. Altomare, D.A.; Vaslet, C.A.; Skele, K.L.; De Rienzo, A.; Devarajan, K.; Jhanwar, S.C.; McClatchey, A.I.; Kane, A.B.; Testa, J.R. A mouse model recapitulating molecular features of human mesothelioma. Cancer Res. 2005, 65, 8090-8095. [CrossRef] [PubMed]

3. Stemmer-Rachamimov, A.O.; Xu, L.; Gonzalez-Agosti, C.; Burwick, J.A.; Pinney, D.; Beauchamp, R.; Jacoby, L.B.; Gusella, J.F.; Ramesh, V.; Louis, D.N. Universal absence of merlin, but not other ERM family members, in schwannomas. Am. J. Pathol. 1997, 151, 1649-1654. [PubMed]

4. Ruttledge, M.H.; Sarrazin, J.; Rangaratnam, S.; Phelan, C.M.; Twist, E.; Merel, P.; Delattre, O.; Thomas, G.; Nordenskjold, M.; Collins, V.P.; et al. Evidence for the complete inactivation of the NF2 gene in the majority of sporadic meningiomas. Nat. Genet. 1994, 6, 180-184. [CrossRef] [PubMed]

5. Sekido, Y.; Pass, H.I.; Bader, S.; Mew, D.J.; Christman, M.F.; Gazdar, A.F.; Minna, J.D. Neurofibromatosis type 2 (NF2) gene is somatically mutated in mesothelioma but not in lung cancer. Cancer Res. 1995, 55, 1227-1231. [PubMed]

6. Bianchi, A.B.; Mitsunaga, S.I.; Cheng, J.Q.; Klein, W.M.; Jhanwar, S.C.; Seizinger, B.; Kley, N.; Klein-Szanto, A.J.; Testa, J.R. High frequency of inactivating mutations in the neurofibromatosis type 2 gene (NF2) in primary malignant mesotheliomas. Proc. Natl. Acad. Sci. USA 1995, 92, 10854-10858. [CrossRef] [PubMed] 
7. Li, W.; Cooper, J.; Karajannis, M.A.; Giancotti, F.G. Merlin: A tumour suppressor with functions at the cell cortex and in the nucleus. EMBO Rep. 2012, 13, 204-215. [CrossRef] [PubMed]

8. Petrilli, A.M.; Fernandez-Valle, C. Role of Merlin/NF2 inactivation in tumor biology. Oncogene 2016, 35, 537-548. [CrossRef] [PubMed]

9. McClatchey, A.I.; Saotome, I.; Ramesh, V.; Gusella, J.F.; Jacks, T. The NF2 tumor suppressor gene product is essential for extraembryonic development immediately prior to gastrulation. Genes Dev. 1997, 11, 1253-1265. [CrossRef] [PubMed]

10. Giovannini, M.; Robanus-Maandag, E.; van der Valk, M.; Niwa-Kawakita, M.; Abramowski, V.; Goutebroze, L.; Woodruff, J.M.; Berns, A.; Thomas, G. Conditional biallelic NF2 mutation in the mouse promotes manifestations of human neurofibromatosis type 2. Genes Dev. 2000, 14, 1617-1630. [PubMed]

11. McClatchey, A.I.; Saotome, I.; Mercer, K.; Crowley, D.; Gusella, J.F.; Bronson, R.T.; Jacks, T. Mice heterozygous for a mutation at the NF2 tumor suppressor locus develop a range of highly metastatic tumors. Genes Dev. 1998, 12, 1121-1133. [CrossRef] [PubMed]

12. Thurneysen, C.; Opitz, I.; Kurtz, S.; Weder, W.; Stahel, R.A.; Felley-Bosco, E. Functional inactivation of NF2/merlin in human mesothelioma. Lung Cancer 2009, 64, 140-147. [CrossRef] [PubMed]

13. Jongsma, J.; van Montfort, E.; Vooijs, M.; Zevenhoven, J.; Krimpenfort, P.; van der Valk, M.; van de Vijver, M.; Berns, A. A conditional mouse model for malignant mesothelioma. Cancer Cell 2008, 13, 261-271. [CrossRef] [PubMed]

14. Poulikakos, P.I.; Xiao, G.H.; Gallagher, R.; Jablonski, S.; Jhanwar, S.C.; Testa, J.R. Re-expression of the tumor suppressor NF2/merlin inhibits invasiveness in mesothelioma cells and negatively regulates FAK. Oncogene 2006, 25, 5960-5968. [CrossRef] [PubMed]

15. Kato, T.; Sato, T.; Yokoi, K.; Sekido, Y. E-cadherin expression is correlated with focal adhesion kinase inhibitor resistance in Merlin-negative malignant mesothelioma cells. Oncogene 2017, 36, 5522-5531. [CrossRef] [PubMed]

16. Xiao, G.H.; Gallagher, R.; Shetler, J.; Skele, K.; Altomare, D.A.; Pestell, R.G.; Jhanwar, S.; Testa, J.R. The NF2 tumor suppressor gene product, merlin, inhibits cell proliferation and cell cycle progression by repressing cyclin D1 expression. Mol. Cell. Biol. 2005, 25, 2384-2394. [CrossRef] [PubMed]

17. Rouleau, G.A.; Merel, P.; Lutchman, M.; Sanson, M.; Zucman, J.; Marineau, C.; Hoang-Xuan, K.; Demczuk, S.; Desmaze, C.; Plougastel, B.; et al. Alteration in a new gene encoding a putative membrane-organizing protein causes neuro-fibromatosis type 2. Nature 1993, 363, 515-521. [CrossRef] [PubMed]

18. Chang, L.S.; Akhmametyeva, E.M.; Wu, Y.; Zhu, L.; Welling, D.B. Multiple transcription initiation sites, alternative splicing, and differential polyadenylation contribute to the complexity of human neurofibromatosis 2 transcripts. Genomics 2002, 79, 63-76. [CrossRef] [PubMed]

19. Gutmann, D.H.; Sherman, L.; Seftor, L.; Haipek, C.; Hoang Lu, K.; Hendrix, M. Increased expression of the NF2 tumor suppressor gene product, merlin, impairs cell motility, adhesionand spreading. Hum. Mol. Genet. 1999, 8, 267-275. [CrossRef] [PubMed]

20. Sherman, L.; Xu, H.M.; Geist, R.T.; Saporito-Irwin, S.; Howells, N.; Ponta, H.; Herrlich, P.; Gutmann, D.H. Interdomain binding mediates tumor growth suppression by the NF2 gene product. Oncogene 1997, 15, 2505-2509. [CrossRef] [PubMed]

21. Lallemand, D.; Saint-Amaux, A.L.; Giovannini, M. Tumor-suppression functions of merlin are independent of its role as an organizer of the actin cytoskeleton in Schwann cells. J. Cell Sci. 2009, 122, 4141-4149. [CrossRef] [PubMed]

22. Zoch, A.; Mayerl, S.; Schulz, A.; Greither, T.; Frappart, L.; Rubsam, J.; Heuer, H.; Giovannini, M.; Morrison, H. Merlin Isoforms 1 and 2 Both Act as Tumour Suppressors and Are Required for Optimal Sperm Maturation. PLoS ONE 2015, 10, e0129151. [CrossRef] [PubMed]

23. Sher, I.; Hanemann, C.O.; Karplus, P.A.; Bretscher, A. The tumor suppressor merlin controls growth in its open state, and phosphorylation converts it to a less-active more-closed state. Dev. Cell 2012, 22, 703-705. [CrossRef] [PubMed]

24. Bueno, R.; Stawiski, E.W.; Goldstein, L.D.; Durinck, S.; De Rienzo, A.; Modrusan, Z.; Gnad, F.; Nguyen, T.T.; Jaiswal, B.S.; Chirieac, L.R.; et al. Comprehensive genomic analysis of malignant pleural mesothelioma identifies recurrent mutations, gene fusions and splicing alterations. Nat. Genet. 2016, 48, 407-416. [CrossRef] [PubMed] 
25. McClatchey, A.I.; Giovannini, M. Membrane organization and tumorigenesis-The NF2 tumor suppressor, Merlin. Genes Dev. 2005, 19, 2265-2277. [CrossRef] [PubMed]

26. Morrison, H.; Sherman, L.S.; Legg, J.; Banine, F.; Isacke, C.; Haipek, C.A.; Gutmann, D.H.; Ponta, H.; Herrlich, P. The NF2 tumor suppressor gene product, merlin, mediates contact inhibition of growth through interactions with CD44. Genes Dev. 2001, 15, 968-980. [CrossRef] [PubMed]

27. Sainio, M.; Zhao, F.; Heiska, L.; Turunen, O.; den Bakker, M.; Zwarthoff, E.; Lutchman, M.; Rouleau, G.A.; Jaaskelainen, J.; Vaheri, A.; et al. Neurofibromatosis 2 tumor suppressor protein colocalizes with ezrin and CD44 and associates with actin-containing cytoskeleton. J. Cell Sci. 1997, 110 Pt 18, 2249-2260. [PubMed]

28. Murthy, A.; Gonzalez-Agosti, C.; Cordero, E.; Pinney, D.; Candia, C.; Solomon, F.; Gusella, J.; Ramesh, V. NHE-RF, a regulatory cofactor for $\mathrm{Na}^{+}-\mathrm{H}^{+}$exchange, is a common interactor for merlin and ERM (MERM) proteins. J. Biol. Chem. 1998, 273, 1273-1276. [CrossRef] [PubMed]

29. Reczek, D.; Berryman, M.; Bretscher, A. Identification of EBP50: A PDZ-containing phosphoprotein that associates with members of the ezrin-radixin-moesin family. J. Cell Biol. 1997, 139, 169-179. [CrossRef] [PubMed]

30. Lallemand, D.; Curto, M.; Saotome, I.; Giovannini, M.; McClatchey, A.I. NF2 deficiency promotes tumorigenesis and metastasis by destabilizing adherens junctions. Genes Dev. 2003, 17, 1090-1100. [CrossRef] [PubMed]

31. Fehon, R.G.; McClatchey, A.I.; Bretscher, A. Organizing the cell cortex: The role of ERM proteins. Nat. Rev. Mol. Cell Biol. 2010, 11, 276-287. [CrossRef] [PubMed]

32. Mani, T.; Hennigan, R.F.; Foster, L.A.; Conrady, D.G.; Herr, A.B.; Ip, W. FERM domain phosphoinositide binding targets merlin to the membrane and is essential for its growth-suppressive function. Mol. Cell. Biol. 2011, 31, 1983-1996. [CrossRef] [PubMed]

33. Hamada, K.; Shimizu, T.; Matsui, T.; Tsukita, S.; Hakoshima, T. Structural basis of the membrane-targeting and unmasking mechanisms of the radixin FERM domain. EMBO J. 2000, 19, 4449-4462. [CrossRef] [PubMed]

34. Shimizu, T.; Seto, A.; Maita, N.; Hamada, K.; Tsukita, S.; Tsukita, S.; Hakoshima, T. Structural basis for neurofibromatosis type 2. Crystal structure of the merlin FERM domain. J. Biol. Chem. 2002, 277, 10332-10336. [CrossRef] [PubMed]

35. Xu, H.M.; Gutmann, D.H. Merlin differentially associates with the microtubule and actin cytoskeleton. J. Neurosci. Res. 1998, 51, 403-415. [CrossRef]

36. LaJeunesse, D.R.; McCartney, B.M.; Fehon, R.G. Structural analysis of Drosophila merlin reveals functional domains important for growth control and subcellular localization. J. Cell Biol. 1998, 141, 1589-1599. [CrossRef] [PubMed]

37. Johnson, K.C.; Kissil, J.L.; Fry, J.L.; Jacks, T. Cellular transformation by a FERM domain mutant of the NF2 tumor suppressor gene. Oncogene 2002, 21, 5990-5997. [CrossRef] [PubMed]

38. Surace, E.I.; Haipek, C.A.; Gutmann, D.H. Effect of merlin phosphorylation on neurofibromatosis 2 (NF2) gene function. Oncogene 2004, 23, 580-587. [CrossRef] [PubMed]

39. Rong, R.; Surace, E.I.; Haipek, C.A.; Gutmann, D.H.; Ye, K. Serine 518 phosphorylation modulates merlin intramolecular association and binding to critical effectors important for NF2 growth suppression. Oncogene 2004, 23, 8447-8454. [CrossRef] [PubMed]

40. Jin, H.; Sperka, T.; Herrlich, P.; Morrison, H. Tumorigenic transformation by CPI-17 through inhibition of a merlin phosphatase. Nature 2006, 442, 576-579. [CrossRef] [PubMed]

41. Shaw, R.J.; Paez, J.G.; Curto, M.; Yaktine, A.; Pruitt, W.M.; Saotome, I.; O’Bryan, J.P.; Gupta, V.; Ratner, N.; Der, C.J.; et al. The NF2 tumor suppressor, merlin, functions in Rac-dependent signaling. Dev. Cell 2001, 1, 63-72. [CrossRef]

42. Kissil, J.L.; Wilker, E.W.; Johnson, K.C.; Eckman, M.S.; Yaffe, M.B.; Jacks, T. Merlin, the product of the NF2 tumor suppressor gene, is an inhibitor of the p21-activated kinase, Pak1. Mol. Cell 2003, 12, 841-849. [CrossRef]

43. Xiao, G.H.; Beeser, A.; Chernoff, J.; Testa, J.R. p21-activated kinase links Rac/Cdc42 signaling to merlin. J. Biol. Chem. 2002, 277, 883-886. [CrossRef] [PubMed]

44. Alfthan, K.; Heiska, L.; Gronholm, M.; Renkema, G.H.; Carpen, O. Cyclic AMP-dependent protein kinase phosphorylates merlin at serine 518 independently of p21-activated kinase and promotes merlin-ezrin heterodimerization. J. Biol. Chem. 2004, 279, 18559-18566. [CrossRef] [PubMed] 
45. Okada, T.; López-Lago, M.; Giancotti, F.G. Merlin/NF-2 mediates contact inhibition of growth by suppressing recruitment of Rac to the plasma membrane. J. Cell Biol. 2005, 171, 361-371. [CrossRef] [PubMed]

46. Laulajainen, M.; Muranen, T.; Carpen, O.; Gronholm, M. Protein kinase A-mediated phosphorylation of the NF2 tumor suppressor protein merlin at serine 10 affects the actin cytoskeleton. Oncogene 2008, 27, 3233-3243. [CrossRef] [PubMed]

47. Tang, X.; Jang, S.W.; Wang, X.; Liu, Z.; Bahr, S.M.; Sun, S.Y.; Brat, D.; Gutmann, D.H.; Ye, K. AKT phosphorylation regulates the tumour-suppressor merlin through ubiquitination and degradation. Nat. Cell Biol. 2007, 9, 1199-1207. [CrossRef] [PubMed]

48. Yi, C.; Troutman, S.; Fera, D.; Stemmer-Rachamimov, A.; Avila, J.L.; Christian, N.; Persson, N.L.; Shimono, A.; Speicher, D.W.; Marmorstein, R.; et al. A tight junction-associated Merlin-angiomotin complex mediates Merlin's regulation of mitogenic signaling and tumor suppressive functions. Cancer Cell 2011, 19, 527-540. [CrossRef] [PubMed]

49. Nguyen, R.; Reczek, D.; Bretscher, A. Hierarchy of merlin and ezrin N- and C-terminal domain interactions in homo- and heterotypic associations and their relationship to binding of scaffolding proteins EBP50 and E3KARP. J. Biol. Chem. 2001, 276, 7621-7629. [CrossRef] [PubMed]

50. Hennigan, R.F.; Foster, L.A.; Chaiken, M.F.; Mani, T.; Gomes, M.M.; Herr, A.B.; Ip, W. Fluorescence resonance energy transfer analysis of merlin conformational changes. Mol. Cell. Biol. 2010, 30, 54-67. [CrossRef] [PubMed]

51. Gutmann, D.H.; Hirbe, A.C.; Haipek, C.A. Functional analysis of neurofibromatosis 2 (NF2) missense mutations. Hum. Mol. Genet. 2001, 10, 1519-1529. [CrossRef] [PubMed]

52. Singhi, A.D.; Krasinskas, A.M.; Choudry, H.A.; Bartlett, D.L.; Pingpank, J.F.; Zeh, H.J.; Luvison, A.; Fuhrer, K.; Bahary, N.; Seethala, R.R.; et al. The prognostic significance of BAP1, NF2, and CDKN2A in malignant peritoneal mesothelioma. Mod. Pathol. 2016, 29, 14-24. [CrossRef] [PubMed]

53. Hanahan, D.; Weinberg, R.A. Hallmarks of cancer: The next generation. Cell 2011, 144, 646-674. [CrossRef] [PubMed]

54. Bosco, E.E.; Nakai, Y.; Hennigan, R.F.; Ratner, N.; Zheng, Y. NF2-deficient cells depend on the Rac1-canonical Wnt signaling pathway to promote the loss of contact inhibition of proliferation. Oncogene 2010, 29, 2540-2549. [CrossRef] [PubMed]

55. Gladden, A.B.; Hebert, A.M.; Schneeberger, E.E.; McClatchey, A.I. The NF2 tumor suppressor, Merlin, regulates epidermal development through the establishment of a junctional polarity complex. Dev. Cell 2010, 19, 727-739. [CrossRef] [PubMed]

56. Gonzalez-Agosti, C.; Xu, L.; Pinney, D.; Beauchamp, R.; Hobbs, W.; Gusella, J.; Ramesh, V. The merlin tumor suppressor localizes preferentially in membrane ruffles. Oncogene 1996, 13, 1239-1247. [PubMed]

57. Scherer, S.S.; Gutmann, D.H. Expression of the neurofibromatosis 2 tumor suppressor gene product, merlin, in Schwann cells. J. Neurosci. Res. 1996, 46, 595-605. [CrossRef]

58. Yokoyama, T.; Osada, H.; Murakami, H.; Tatematsu, Y.; Taniguchi, T.; Kondo, Y.; Yatabe, Y.; Hasegawa, Y.; Shimokata, K.; Horio, Y.; et al. YAP1 is involved in mesothelioma development and negatively regulated by Merlin through phosphorylation. Carcinogenesis 2008, 29, 2139-2146. [CrossRef] [PubMed]

59. Harvey, K.F.; Zhang, X.; Thomas, D.M. The Hippo pathway and human cancer. Nat. Rev. Cancer 2013, 13, 246-257. [CrossRef] [PubMed]

60. Zanconato, F.; Cordenonsi, M.; Piccolo, S. YAP/TAZ at the Roots of Cancer. Cancer Cell 2016, 29, $783-803$. [CrossRef] [PubMed]

61. Tanaka, I.; Osada, H.; Fujii, M.; Fukatsu, A.; Hida, T.; Horio, Y.; Kondo, Y.; Sato, A.; Hasegawa, Y.; Tsujimura, T.; et al. LIM-domain protein AJUBA suppresses malignant mesothelioma cell proliferation via Hippo signaling cascade. Oncogene 2015, 34, 73-83. [CrossRef] [PubMed]

62. Murakami, H.; Mizuno, T.; Taniguchi, T.; Fujii, M.; Ishiguro, F.; Fukui, T.; Akatsuka, S.; Horio, Y.; Hida, T.; Kondo, Y.; et al. LATS2 is a tumor suppressor gene of malignant mesothelioma. Cancer Res. 2011, 71, 873-883. [CrossRef] [PubMed]

63. Kakiuchi, T.; Takahara, T.; Kasugai, Y.; Arita, K.; Yoshida, N.; Karube, K.; Suguro, M.; Matsuo, K.; Nakanishi, H.; Kiyono, T.; et al. Modeling mesothelioma utilizing human mesothelial cells reveals involvement of phospholipase-C $\beta 4$ in YAP-active mesothelioma cell proliferation. Carcinogenesis 2016, 37, 1098-1109. [CrossRef] [PubMed] 
64. Mizuno, T.; Murakami, H.; Fujii, M.; Ishiguro, F.; Tanaka, I.; Kondo, Y.; Akatsuka, S.; Toyokuni, S.; Yokoi, K.; Osada, H.; et al. YAP induces malignant mesothelioma cell proliferation by upregulating transcription of cell cycle-promoting genes. Oncogene 2012, 31, 5117-5122. [CrossRef] [PubMed]

65. Li, W.; You, L.; Cooper, J.; Schiavon, G.; Pepe-Caprio, A.; Zhou, L.; Ishii, R.; Giovannini, M.; Hanemann, C.O.; Long, S.B.; et al. Merlin/NF2 suppresses tumorigenesis by inhibiting the E3 ubiquitin ligase CRL4(DCAF1) in the nucleus. Cell 2010, 140, 477-490. [CrossRef] [PubMed]

66. Li, W.; Cooper, J.; Zhou, L.; Yang, C.; Erdjument-Bromage, H.; Zagzag, D.; Snuderl, M.; Ladanyi, M.; Hanemann, C.O.; Zhou, P.; et al. Merlin/NF2 loss-driven tumorigenesis linked to CRL4(DCAF1)-mediated inhibition of the Hippo pathway kinases LATS1 and 2 in the nucleus. Cancer Cell 2014, 26, 48-60. [CrossRef] [PubMed]

67. Cooper, J.; Xu, Q.; Zhou, L.; Pavlovic, M.; Ojeda, V.; Moulick, K.; de Stanchina, E.; Poirier, J.T.; Zauderer, M.; Rudin, C.M.; et al. Combined Inhibition of NEDD8-Activating Enzyme and mTOR Suppresses NF2 Loss-Driven Tumorigenesis. Mol. Cancer Ther. 2017, 16, 1693-1704. [CrossRef] [PubMed]

68. Hikasa, H.; Sekido, Y.; Suzuki, A. Merlin/NF2-Lin28B-let-7 Is a Tumor-Suppressive Pathway that Is Cell-Density Dependent and Hippo Independent. Cell Rep. 2016, 14, 2950-2961. [CrossRef] [PubMed]

69. Saxton, R.A.; Sabatini, D.M. mTOR Signaling in Growth, Metabolism, and Disease. Cell 2017, 168, $960-976$. [CrossRef] [PubMed]

70. Albert, V.; Hall, M.N. mTOR signaling in cellular and organismal energetics. Curr. Opin. Cell Biol. 2015, 33, 55-66. [CrossRef] [PubMed]

71. Yang, H.; Rudge, D.G.; Koos, J.D.; Vaidialingam, B.; Yang, H.J.; Pavletich, N.P. mTOR kinase structure, mechanism and regulation. Nature 2013, 497, 217-223. [CrossRef] [PubMed]

72. Sato, T.; Akasu, H.; Shimono, W.; Matsu, C.; Fujiwara, Y.; Shibagaki, Y.; Heard, J.J.; Tamanoi, F.; Hattori, S. Rheb protein binds CAD (carbamoyl-phosphate synthetase 2, aspartate transcarbamoylase, and dihydroorotase) protein in a GTP- and effector domain-dependent manner and influences its cellular localization and carbamoyl-phosphate synthetase (CPSase) activity. J. Biol. Chem. 2015, 290, 1096-1105. [CrossRef] [PubMed]

73. Robitaille, A.M.; Christen, S.; Shimobayashi, M.; Cornu, M.; Fava, L.L.; Moes, S.; Prescianotto-Baschong, C.; Sauer, U.; Jenoe, P.; Hall, M.N. Quantitative phosphoproteomics reveal mTORC1 activates de novo pyrimidine synthesis. Science 2013, 339, 1320-1323. [CrossRef] [PubMed]

74. Ben-Sahra, I.; Howell, J.J.; Asara, J.M.; Manning, B.D. Stimulation of de novo pyrimidine synthesis by growth signaling through mTOR and S6K1. Science 2013, 339, 1323-1328. [CrossRef] [PubMed]

75. López -Lago, M.A.; Okada, T.; Murillo, M.M.; Socci, N.; Giancotti, F.G. Loss of the tumor suppressor gene NF2, encoding merlin, constitutively activates integrin-dependent mTORC1 signaling. Mol. Cell. Biol. 2009, 29, 4235-4249. [CrossRef] [PubMed]

76. James, M.F.; Han, S.; Polizzano, C.; Plotkin, S.R.; Manning, B.D.; Stemmer-Rachamimov, A.O.; Gusella, J.F.; Ramesh, V. NF2/merlin is a novel negative regulator of mTOR complex 1, and activation of mTORC1 is associated with meningioma and schwannoma growth. Mol. Cell. Biol. 2009, 29, 4250-4261. [CrossRef] [PubMed]

77. Guo, Y.; Chirieac, L.R.; Bueno, R.; Pass, H.; Wu, W.; Malinowska, I.A.; Kwiatkowski, D.J. Tsc1-Tp53 loss induces mesothelioma in mice, and evidence for this mechanism in human mesothelioma. Oncogene 2014, 33, 3151-3160. [CrossRef] [PubMed]

78. Altomare, D.A.; You, H.; Xiao, G.H.; Ramos-Nino, M.E.; Skele, K.L.; De Rienzo, A.; Jhanwar, S.C.; Mossman, B.T.; Kane, A.B.; Testa, J.R. Human and mouse mesotheliomas exhibit elevated AKT/PKB activity, which can be targeted pharmacologically to inhibit tumor cell growth. Oncogene 2005, 24, 6080-6089. [CrossRef] [PubMed]

79. Suzuki, Y.; Murakami, H.; Kawaguchi, K.; Tanigushi, T.; Fujii, M.; Shinjo, K.; Kondo, Y.; Osada, H.; Shimokata, K.; Horio, Y.; et al. Activation of the PI3K-AKT pathway in human malignant mesothelioma cells. Mol. Med. Rep. 2009, 2, 181-188. [PubMed]

80. Sato, T.; Nakashima, A.; Guo, L.; Coffman, K.; Tamanoi, F. Single amino-acid changes that confer constitutive activation of mTOR are discovered in human cancer. Oncogene 2010, 29, 2746-2752. [CrossRef] [PubMed]

81. Grabiner, B.C.; Nardi, V.; Birsoy, K.; Possemato, R.; Shen, K.; Sinha, S.; Jordan, A.; Beck, A.H.; Sabatini, D.M. A diverse array of cancer-associated MTOR mutations are hyperactivating and can predict rapamycin sensitivity. Cancer Discov. 2014, 4, 554-563. [CrossRef] [PubMed] 
82. Rehfeld, F.; Rohde, A.M.; Nguyen, D.T.; Wulczyn, F.G. Lin28 and let-7: Ancient milestones on the road from pluripotency to neurogenesis. Cell Tissue Res. 2015, 359, 145-160. [CrossRef] [PubMed]

83. Zhou, J.; Ng, S.B.; Chng, W.J. LIN28/LIN28B: An emerging oncogenic driver in cancer stem cells. Int. J. Biochem. Cell Biol. 2013, 45, 973-978. [CrossRef] [PubMed]

84. Johnson, S.M.; Grosshans, H.; Shingara, J.; Byrom, M.; Jarvis, R.; Cheng, A.; Labourier, E.; Reinert, K.L.; Brown, D.; Slack, F.J. RAS is regulated by the let-7 microRNA family. Cell 2005, 120, 635-647. [CrossRef] [PubMed]

85. Kumar, M.S.; Lu, J.; Mercer, K.L.; Golub, T.R.; Jacks, T. Impaired microRNA processing enhances cellular transformation and tumorigenesis. Nat. Genet. 2007, 39, 673-677. [CrossRef] [PubMed]

86. Bouwmeester, T.; Bauch, A.; Ruffner, H.; Angrand, P.O.; Bergamini, G.; Croughton, K.; Cruciat, C.; Eberhard, D.; Gagneur, J.; Ghidelli, S.; et al. A physical and functional map of the human TNF- $\alpha / N F-\kappa B$ signal transduction pathway. Nat. Cell Biol. 2004, 6, 97-105. [CrossRef] [PubMed]

87. Scudiero, I.; Zotti, T.; Ferravante, A.; Vessichelli, M.; Reale, C.; Masone, M.C.; Leonardi, A.; Vito, P.; Stilo, R. Tumor necrosis factor (TNF) receptor-associated factor 7 is required for TNF $\alpha$-induced Jun NH2-terminal kinase activation and promotes cell death by regulating polyubiquitination and lysosomal degradation of c-FLIP protein. J. Biol. Chem. 2012, 287, 6053-6061. [CrossRef] [PubMed]

88. Rippo, M.R.; Moretti, S.; Vescovi, S.; Tomasetti, M.; Orecchia, S.; Amici, G.; Catalano, A.; Procopio, A. FLIP overexpression inhibits death receptor-induced apoptosis in malignant mesothelial cells. Oncogene 2004, 23, 7753-7760. [CrossRef] [PubMed]

89. Clark, V.E.; Erson-Omay, E.Z.; Serin, A.; Yin, J.; Cotney, J.; Ozduman, K.; Avsar, T.; Li, J.; Murray, P.B.; Henegariu, O.; et al. Genomic analysis of non-NF2 meningiomas reveals mutations in TRAF7, KLF4, AKT1, and SMO. Science 2013, 339, 1077-1080. [CrossRef] [PubMed]

90. Shapiro, I.M.; Kolev, V.N.; Vidal, C.M.; Kadariya, Y.; Ring, J.E.; Wright, Q.; Weaver, D.T.; Menges, C.; Padval, M.; McClatchey, A.I.; et al. Merlin deficiency predicts FAK inhibitor sensitivity: A synthetic lethal relationship. Sci. Transl. Med. 2014, 6, 237ra68. [CrossRef] [PubMed]

91. Liu-Chittenden, Y.; Huang, B.; Shim, J.S.; Chen, Q.; Lee, S.J.; Anders, R.A.; Liu, J.O.; Pan, D. Genetic and pharmacological disruption of the TEAD-YAP complex suppresses the oncogenic activity of YAP. Genes Dev. 2012, 26, 1300-1305. [CrossRef] [PubMed]

92. Zhang, W.Q.; Dai, Y.Y.; Hsu, P.C.; Wang, H.; Cheng, L.; Yang, Y.L.; Wang, Y.C.; Xu, Z.D.; Liu, S.; Chan, G.; et al. Targeting YAP in malignant pleural mesothelioma. J. Cell. Mol. Med. 2017, 21, 2663-2676. [CrossRef] [PubMed]

93. Tranchant, R.; Quetel, L.; Tallet, A.; Meiller, C.; Renier, A.; de Koning, L.; de Reynies, A.; Le Pimpec-Barthes, F.; Zucman-Rossi, J.; Jaurand, M.C.; et al. Co-occurring Mutations of Tumor Suppressor Genes, LATS2 and NF2, in Malignant Pleural Mesothelioma. Clin. Cancer Res. 2017, 23, 3191-3202. [CrossRef] [PubMed]

94. Shimada, K.; Skouta, R.; Kaplan, A.; Yang, W.S.; Hayano, M.; Dixon, S.J.; Brown, L.M.; Valenzuela, C.A.; Wolpaw, A.J.; Stockwell, B.R. Global survey of cell death mechanisms reveals metabolic regulation of ferroptosis. Nat. Chem. Biol. 2016, 12, 497-503. [CrossRef] [PubMed]

95. Song, S.; Xie, M.; Scott, A.W.; Jin, J.; Ma, L.; Dong, X.; Skinner, H.D.; Johnson, R.L.; Ding, S.; Ajani, J.A. A Novel YAP1 Inhibitor Targets CSC-Enriched Radiation-Resistant Cells and Exerts Strong Antitumor Activity in Esophageal Adenocarcinoma. Mol. Cancer Ther. 2018, 17, 443-454. [CrossRef] [PubMed]

96. Lin, K.C.; Moroishi, T.; Meng, Z.; Jeong, H.S.; Plouffe, S.W.; Sekido, Y.; Han, J.; Park, H.W.; Guan, K.L. Regulation of Hippo pathway transcription factor TEAD by p38 MAPK-induced cytoplasmic translocation. Nat. Cell Biol. 2017, 19, 996-1002. [CrossRef] [PubMed]

97. Ou, S.H.; Moon, J.; Garland, L.L.; Mack, P.C.; Testa, J.R.; Tsao, A.S.; Wozniak, A.J.; Gandara, D.R. SWOG S0722: Phase II study of mTOR inhibitor everolimus (RAD001) in advanced malignant pleural mesothelioma (MPM). J. Thorac. Oncol. 2015, 10, 387-391. [CrossRef] [PubMed]

98. Thoreen, C.C.; Kang, S.A.; Chang, J.W.; Liu, Q.; Zhang, J.; Gao, Y.; Reichling, L.J.; Sim, T.; Sabatini, D.M.; Gray, N.S. An ATP-competitive mammalian target of rapamycin inhibitor reveals rapamycin-resistant functions of mTORC1. J. Biol. Chem. 2009, 284, 8023-8032. [CrossRef] [PubMed]

99. Agarwal, V.; Campbell, A.; Beaumont, K.L.; Cawkwell, L.; Lind, M.J. PTEN protein expression in malignant pleural mesothelioma. Tumour Biol. 2013, 34, 847-851. [CrossRef] [PubMed] 
100. Goel, S.; Wang, Q.; Watt, A.C.; Tolaney, S.M.; Dillon, D.A.; Li, W.; Ramm, S.; Palmer, A.C.; Yuzugullu, H.; Varadan, V.; et al. Overcoming Therapeutic Resistance in HER2-Positive Breast Cancers with CDK4/6 Inhibitors. Cancer Cell 2016, 29, 255-269. [CrossRef] [PubMed]

101. Franco, J.; Balaji, U.; Freinkman, E.; Witkiewicz, A.K.; Knudsen, E.S. Metabolic Reprogramming of Pancreatic Cancer Mediated by CDK4/6 Inhibition Elicits Unique Vulnerabilities. Cell Rep. 2016, 14, 979-990. [CrossRef] [PubMed]

102. Bonelli, M.A.; Digiacomo, G.; Fumarola, C.; Alfieri, R.; Quaini, F.; Falco, A.; Madeddu, D.; La Monica, S.; Cretella, D.; Ravelli, A.; et al. Combined Inhibition of CDK4/6 and PI3K/AKT/mTOR Pathways Induces a Synergistic Anti-Tumor Effect in Malignant Pleural Mesothelioma Cells. Neoplasia 2017, 19, 637-648. [CrossRef] [PubMed]

103. Rodrik-Outmezguine, V.S.; Okaniwa, M.; Yao, Z.; Novotny, C.J.; McWhirter, C.; Banaji, A.; Won, H.; Wong, W.; Berger, M.; de Stanchina, E.; et al. Overcoming mTOR resistance mutations with a new-generation mTOR inhibitor. Nature 2016, 534, 272-276. [CrossRef] [PubMed]

104. Fan, Q.; Aksoy, O.; Wong, R.A.; Ilkhanizadeh, S.; Novotny, C.J.; Gustafson, W.C.; Truong, A.Y.; Cayanan, G.; Simonds, E.F.; Haas-Kogan, D.; et al. A Kinase Inhibitor Targeted to mTORC1 Drives Regression in Glioblastoma. Cancer Cell 2017, 31, 424-435. [CrossRef] [PubMed]

105. Demierre, M.F.; Higgins, P.D.; Gruber, S.B.; Hawk, E.; Lippman, S.M. Statins and cancer prevention. Nat. Rev. Cancer 2005, 5, 930-942. [CrossRef] [PubMed]

106. Rubins, J.B.; Greatens, T.; Kratzke, R.A.; Tan, A.T.; Polunovsky, V.A.; Bitterman, P. Lovastatin induces apoptosis in malignant mesothelioma cells. Am. J. Respir. Crit. Care Med. 1998, 157, 1616-1622. [CrossRef] [PubMed]

107. Asakura, K.; Izumi, Y.; Yamamoto, M.; Yamauchi, Y.; Kawai, K.; Serizawa, A.; Mizushima, T.; Ohmura, M.; Kawamura, M.; Wakui, M.; et al. The cytostatic effects of lovastatin on ACC-MESO-1 cells. J. Surg. Res. 2011, 170, e197-e209. [CrossRef] [PubMed]

108. Yamauchi, Y.; Izumi, Y.; Asakura, K.; Fukutomi, T.; Serizawa, A.; Kawai, K.; Wakui, M.; Suematsu, M.; Nomori, H. Lovastatin and valproic acid additively attenuate cell invasion in ACC-MESO-1 cells. Biochem. Biophys. Res. Commun. 2011, 410, 328-332. [CrossRef] [PubMed]

109. Tuerdi, G.; Ichinomiya, S.; Sato, H.; Siddig, S.; Suwa, E.; Iwata, H.; Yano, T.; Ueno, K. Synergistic effect of combined treatment with gamma-tocotrienol and statin on human malignant mesothelioma cells. Cancer Lett. 2013, 339, 116-127. [CrossRef] [PubMed]

110. Hwang, K.E.; Kim, Y.S.; Hwang, Y.R.; Kwon, S.J.; Park, D.S.; Cha, B.K.; Kim, B.R.; Yoon, K.H.; Jeong, E.T.; Kim, H.R. Enhanced apoptosis by pemetrexed and simvastatin in malignant mesothelioma and lung cancer cells by reactive oxygen species-dependent mitochondrial dysfunction and Bim induction. Int. J. Oncol. 2014, 45, 1769-1777. [CrossRef] [PubMed]

111. Tanaka, K.; Osada, H.; Murakami-Tonami, Y.; Horio, Y.; Hida, T.; Sekido, Y. Statin suppresses Hippo pathway-inactivated malignant mesothelioma cells and blocks the YAP/CD44 growth stimulatory axis. Cancer Lett. 2017, 385, 215-224. [CrossRef] [PubMed]

112. Wang, Z.; Wu, Y.; Wang, H.; Zhang, Y.; Mei, L.; Fang, X.; Zhang, X.; Zhang, F.; Chen, H.; Liu, Y.; et al. Interplay of mevalonate and Hippo pathways regulates RHAMM transcription via YAP to modulate breast cancer cell motility. Proc. Natl. Acad. Sci. USA 2014, 111, E89-E98. [CrossRef] [PubMed]

113. Sorrentino, G.; Ruggeri, N.; Specchia, V.; Cordenonsi, M.; Mano, M.; Dupont, S.; Manfrin, A.; Ingallina, E.; Sommaggio, R.; Piazza, S.; et al. Metabolic control of YAP and TAZ by the mevalonate pathway. Nat. Cell Biol. 2014, 16, 357-366. [CrossRef] [PubMed]

114. Guerrant, W.; Kota, S.; Troutman, S.; Mandati, V.; Fallahi, M.; Stemmer-Rachamimov, A.; Kissil, J.L. YAP Mediates Tumorigenesis in Neurofibromatosis Type 2 by Promoting Cell Survival and Proliferation through a COX-2-EGFR Signaling Axis. Cancer Res. 2016, 76, 3507-3519. [CrossRef] [PubMed]

115. Wahle, B.M.; Hawley, E.T.; He, Y.; Smith, A.E.; Yuan, J.; Masters, A.R.; Jones, D.R.; Gehlhausen, J.R.; Park, S.J.; Conway, S.J.; et al. Chemopreventative celecoxib fails to prevent schwannoma formation or sensorineural hearing loss in genetically engineered murine model of neurofibromatosis type 2. Oncotarget 2018, 9, 718-725. [CrossRef] [PubMed]

116. Yap, T.A.; Aerts, J.G.; Popat, S.; Fennell, D.A. Novel insights into mesothelioma biology and implications for therapy. Nat. Rev. Cancer 2017, 17, 475-488. [CrossRef] [PubMed] 
117. Guo, X.E.; Ngo, B.; Modrek, A.S.; Lee, W.H. Targeting tumor suppressor networks for cancer therapeutics. Curr. Drug Targets 2014, 15, 2-16. [CrossRef] [PubMed]

118. Cooper, J.; Giancotti, F.G. Molecular insights into NF2/Merlin tumor suppressor function. FEBS Lett. 2014, 588, 2743-2752. [CrossRef] [PubMed]

119. McCambridge, A.J.; Napolitano, A.; Mansfield, A.S.; Fennell, D.A.; Sekido, Y.; Nowak, A.K.; Reungwetwattana, T.; Mao, W.; Pass, H.I.; Carbone, M.; et al. State of the art: Advances in Malignant Pleural Mesothelioma in 2017. J. Thorac. Oncol. 2018, in press. [CrossRef] [PubMed]

120. Shalem, O.; Sanjana, N.E.; Hartenian, E.; Shi, X.; Scott, D.A.; Mikkelson, T.; Heckl, D.; Ebert, B.L.; Root, D.E.; Doench, J.G.; et al. Genome-scale CRISPR-Cas9 knockout screening in human cells. Science 2014, 343, 84-87. [CrossRef] [PubMed]

(C) 2018 by the authors. Licensee MDPI, Basel, Switzerland. This article is an open access article distributed under the terms and conditions of the Creative Commons Attribution (CC BY) license (http:/ / creativecommons.org/licenses/by/4.0/). 